\title{
Serum levels of angiopoietin-related growth factor in diabetes mellitus and chronic hemodialysis
}

\section{Kronik hemodializ ve diabetes mellituslu hastalarda angiopoietin-related growth faktör düzeyleri}

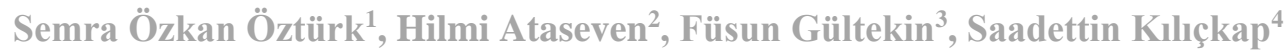

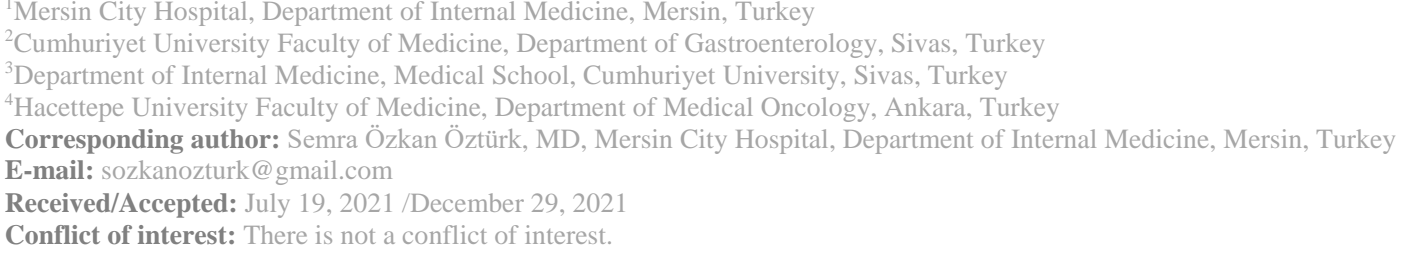

\section{SUMMARY}

Obesity is an increasing health problem all over the world. Angiopoietinrelated growth factor (AGF, ANGPTL6) is a hepatocyte that directly regulates lipid, glucose and energy metabolism independent of angiogenic effects. In this study, we investigated circulating AGF levels in relation to kidney function, type 2 diabetes mellitus and insulin resistance. Angiopoietin-related growth factor was determined by enzyme-linked immunosorbent assay in subjects with a normal glomerular filtration rate (n $=44,22$ diabetic and 22 nondiabetic) and in patients on chronic hemodialysis ( $C D ; n=44,22$ diabetic and 22 nondiabetic). Median serum AGF levels were $176,6 \pm 96,6 \mu \mathrm{g} / \mathrm{L}$ inpatients who underwent dialysis and $186,0 \pm 81,7 \mu \mathrm{g} / \mathrm{L}$ in patients not on dialysis. There was no statistically significant difference between the mean serum AGF levels of the patients who underwent dialysis and those who did not $(\mathrm{p}>0.05)$. AGF serum levels were significantly increased in diabetic patients $(222,56 \pm 90,61 \mu \mathrm{g} / \mathrm{L})$ as compared with non-diabetic patients $(140,12 \pm 66,06 \mu \mathrm{g} / \mathrm{L})(\mathrm{P}<0.05)$. In addition, we evaluated the relationship between biochemical parameters and anthropometric measurements of the patients and AGF in our study. BMI, HOMA, waist/hip circumference ratios positively correlated with circulating AGF in all patients. Our results suggest that T2DM is positively associated with AGF serum levels. We think that this study will be useful to explain the pathogenesis of AGF in insulin resistance. Further studies are needed to better elucidate the physiologic significance of circulating AGF in human.

Keywords: Angiopoietin-related growth factor, diabetes mellitus, insulin resistance, chronic hemodialysis
Semra Özkan Öztürk

(D) Hilmi Ataseven

Füsun Gültekin

Saadettin K1lıçkap

ORCID IDs of the authors:

S.Ö.Ö. 0000-0003-2223-197X

H.A. 0000-0001-5458-509X

F.G. 0000-0000-0000-0000

S.K. 0000-0003-1637-7390 
olmayan) . kronik hemodializ hastalarında ortalama serum AGF düzeyleri 176,6 96,6 $\mu \mathrm{g} / \mathrm{L}$ ve diyaliz almayan hastalarda $186,0 \pm 81,7 \mu \mathrm{g} / \mathrm{L}$ idi. Diyalize giren ve girmeyen hastaların ortalama serum AGF düzeyleri arasında istatistiksel olarak anlamlı fark yoktu $(\mathrm{p}>0.05)$. AGF serum seviyeleri diyabetik hastalarda $(222,56 \pm 90,61 \mu \mathrm{g} / \mathrm{L})$ diyabetik olmayan hastalarla $(140,12 \pm 66,06 \mu \mathrm{g} / \mathrm{L})$ karşılaştırıldığında önemli ölçüde arttı $(\mathrm{P}<0.05)$. Ayrıca çalışmamızda hastaların biyokimyasal parametreleri ile antropometrik ölçümleri ile AGF arasındaki ilişkiyi değerlendirdik. BMI, HOMA, bel/kalça çevresi oranları tüm hastalarda dolaşımdaki AGF ile pozitif korelasyon gösterdi. Sonuçlarımız, T2DM'nin AGF serum seviyeleri ile pozitif ilişkili olduğunu göstermektedir. Bu çalışmanın insülin direncinde AGF'nin patogenezini açıklamak için faydalı olacağını düşünüyoruz. İnsanda dolaşan AGF'nin fizyolojik önemini daha iyi aydınlatmak için daha fazla çalışmaya ihtiyaç vardır.

Anahtar sözcükler: Angiopoietin- related growth faktör, diabetes mellitus, insülin direnci, kronik hemodializ.

\section{INTRODUCTION}

Obesity and related metabolic diseases, such as type 2 diabetes, hypertension and hyperlipidemia are an increasingly prevalent medical and social problem in developed and developing countries. These conditions are associated with increased risk of cardiovascular disease, the leading cause of death. A major metabolic manifestation of obesity in the early phase is systemic insulin resistance ${ }^{1}$.

Type 2 diabetes mellitus decreased insulin sensitivity and beta cell dysfunction in liver, muscle and adipose tissue characterized by dysfunction. Decreased insulin sensitivity, insufficient insulin secretion, and increased insulin sensitivity in chronic kidney failure and hepatic gluconeogenesis contributes to insulin resistance.

In patients with $\mathrm{CKD}$, the response to intravenous insulin is impaired and glucose is decreased use by peripheral tissues. In addition, the response to hyperglycemia insulin secretion is also impaired due to impaired pancreatic beta cell response is impaired ${ }^{3}$. C-reactive protein (CRP), a marker of inflammation it is an indicator of endothelial dysfunction and it is correlated with insulin resistance ${ }^{4}$.

Angiopoietin-related growth factor (AGF or ANGPTL6) is a liver-derived, circulating factor and is considered to be a regulator of metabolic homeostasis. AGF is capable of counteracting both obesity and obesity-related insulin resistance. However, the target tissues and the molecular mechanisms underlying the anti-obesity and antidiabetic actions of AGF have not been completely defined .

AGF levels have been positively correlated with fasting serum glucose levels ${ }^{5}$. These findings raise the possibility that ANGPTL6/AGF resistance occurs in obese or diabetic conditions.
Animal knockout and transgenic studies have shown that ANGPTL6 counteracts diet-induced obesity and insulin resistance via increasing energy expenditure $e^{6,7}$.

This study aimed to evaluate the relationship of AGF with type $2 \mathrm{DM}$ and renal functions.

\section{MATERIAL AND METHODS}

\section{Study design and patient selection}

The study group consisted of patients who were admitted to the Department of İnternal Medicine and Nephrology of Cumhuriyet University Hospital between November 2010 and January 2011.

Approval was obtained from the Sivas Clinical Research Ethics Committee dated 29.09.2010 and with the decision numbered 2010-06/62.

A total of 88 cases were included in the study.

Various rheumatological diseases with general inflammation, end-stage patients with malignancy were excluded from the study.

The cases were divided into four subgroups:

1. Control group with non-diabetic and normal glomerular filtration rate $(n=22)$.

2. Non- diabetic chronic hemodialysis patient $(\mathrm{n}=22)$

3. Patients on chronic hemodialysis and type 2diabetes mellitus $(n=22)$.

4.Patients on type 2 diabetes mellitus and normal glomerular filtration rate $(n=22)$.

The female/male ratio was equal in the subgroups. No significant difference between the ages in the subgroups $(\mathrm{p}=0.16)$.

44 patients were undergoing hemodialysis. The duration of hemodialysis varies between 1 month and 20 years. Average dialysis duration was 27 months. The creatinine clearance of the remaining patients was within normal values. 
Type 2 DM was diagnosed with a fasting blood sugar of at least $126 \mathrm{mg} / \mathrm{dl}$. Patients using oral hypoglycemic agents were included in the study. The duration of tip 2 diabetes mellitus ranged from 1-26 years, and the mean duration of the disease was 4.4 years.

Diabetes mellitus diagnosis was excluded by OGTT in the control and non-diabetic groups. Blood collection was intravenously performed in the morning after overnight fasting (12 hour).

Serum levels of fasting blood sugar $(\mathrm{mg} / \mathrm{dl})$, fasting insulin level $(\mathrm{mg} / \mathrm{dl})$, triglyceride $(\mathrm{mg} / \mathrm{dl})$, total cholesterol $(\mathrm{mg} / \mathrm{dl})$, high-density lipoprotein (HDL, mg/dl), low-density lipoprotein (LDL, $\mathrm{mg} / \mathrm{dl})$, creatinine $(\mathrm{mg} / \mathrm{dl})$, albumin $(\mathrm{g} / \mathrm{dl})$, Parathormone (intact, $\mathrm{pg} / \mathrm{ml}$ ), c reactive protein (mg / L) were measured using the standard techniques of clinical chemistry laboratories and used for clinical analysis.

Creatinine clearance was calculated by the Cockroft-Gault formula.

Following the measurement of height and weight, the calculation of body mass index (BMI) was achieved by dividing the weight $(\mathrm{kg})$ by the squared height $\left(\mathrm{m}^{2}\right)$. Height, weight, and waist circumference were measured and converted to the nearest half-cm or half-kg units.

The waist hip circumference ratio (WHR)was calculated by dividing the waist circumference by the hip circumference.

For the AGF level, blood samples were taken between 8:00 and 9:00 am, fasting for twelve hours. The sample was frozen at $-20^{\circ} \mathrm{C}$ and stored for 1 month. Quantification of serum ANGPTL6 concentrations was performed using a commercially available ELISA kit (USCN, E82468H ANGPTL-6, China).

Insulin resistance was calculated with the HOMA(homeostasis model of assessment) formula. Patients with a HOMA score of $\geq 2.5$ were considered positive for insulin resistance.

\section{Statistical analysis}

All data were analyzed using SPSS 14.0 for windows. Kruskal-Wallis test, Mann Whitney U test and correlation analysis was used.

Continuous variables were presented as mean \pm standard deviation (SD), or median and minimummaximum values where appropriate. Categorical variables were expressed as counts and percentages. The results were within the $95 \%$ confidence interval. A $p$ value of $<0.05$ was accepted as statistically significant.

\section{RESULTS}

The study included a total of 88 participants. The female/male ratio was equal in the subgroups. No significant difference between the ages in the subgroups $(\mathrm{p}=0.16)$.

Table 1: Summarizes the demographic and biochemical findings of the groups.

AGF levels of the groups are shown in Table 2.

Serum AGF level showed no significant correlation with chronic hemodialysis patients. The results are shown in table 3 .

Serum AGF level showed significant correlation with diabetic patients. The results are shown in table 4.

Serum AGF level showed significant positive correlation VKI, HOMA, WHR. Serum AGF level showed significant positive correlation fasting blood sugar, fasting Insulin, c reactive protein. Serum AGF level showed no significant correlation with LDL cholesterol, total cholesterol, albümin, creatinine, creatinine clearance, parathormon, triglyceride. Serum AGF level showed significant negative correlation HDL. 
Table 1: Demographic and biochemical findings of the groups

\begin{tabular}{|c|c|c|c|c|c|}
\hline Measurements & $\begin{array}{l}\text { 1. Group } \\
\text { Control }(\mathrm{n}=22) \\
\text { Mean } \pm \mathrm{SD}\end{array}$ & $\begin{array}{l}\text { 2. Group } \\
\text { Diabetic and } \\
\text { normal GFR } \\
(\mathrm{n}=22) \\
\text { Mean } \pm \mathrm{SD}\end{array}$ & $\begin{array}{l}\text { 3. Group } \\
\text { Diabetic and } \\
\text { chronic } \\
\text { hemodialysis } \\
(\mathrm{n}=22) \\
\text { Mean } \pm \mathrm{SD}\end{array}$ & $\begin{array}{l}\text { 4.Group } \\
\text { Non-diabetic and } \\
\text { chronic hemodialysis } \\
(\mathrm{n}=22) \\
\text { Mean } \pm \mathrm{SD}\end{array}$ & Result \\
\hline HOMA-IR & $2,0 \pm 1,2$ & $8,2 \pm 5,3$ & $6,5 \pm 6,4$ & $1,3 \pm 0,3$ & $\begin{array}{l}\mathrm{KW}=41,9 \\
\mathrm{P}=0,001\end{array}$ \\
\hline VKI & $28,0 \pm 6,0$ & $31,6 \pm 5,5$ & $27,5 \pm 5,4$ & $25,9 \pm 5,9$ & $\begin{array}{l}\mathrm{KW}=11,6 \\
\mathrm{P}=0,009\end{array}$ \\
\hline WHR & $0,9 \pm, 01$ & $0,9 \pm, 01$ & $0,8 \pm 0,1$ & $0,8 \pm 0,1$ & $\begin{array}{l}\mathrm{KW}=13,7 \\
\mathrm{P}=0,003\end{array}$ \\
\hline $\begin{array}{l}\text { Fasting } \\
\text { Insulin(mg/dL) }\end{array}$ & $9,5 \pm 5,8$ & $21,0 \pm 7,6$ & $13,9 \pm 12,4$ & $5,8 \pm 5,7$ & $\begin{array}{l}\mathrm{KW}=32,2 \\
\mathrm{P}=0,001^{*}\end{array}$ \\
\hline $\begin{array}{l}\text { Fasting blood } \\
\text { glucose }\end{array}$ & $81,1 \pm 11,8$ & $173,2 \pm 57,9$ & $184,0 \pm 59,5$ & $93,9 \pm 29,6$ & $\begin{array}{l}\mathrm{KW}=55,5 \\
\mathrm{P}=0,001^{*}\end{array}$ \\
\hline $\begin{array}{l}\text { Triglycerid } \\
(\mathrm{mg} / \mathrm{dl})\end{array}$ & $137,0 \pm 80,3$ & $127,5 \pm 77,8$ & $173,0 \pm 133,1$ & $133,8 \pm 94,3$ & $\begin{array}{l}\mathrm{KW}=2,8 \\
\mathrm{P}=0,417\end{array}$ \\
\hline $\begin{array}{l}\text { LDL cholesterol } \\
(\mathrm{mg} / \mathrm{dl})\end{array}$ & $116,2 \pm 44,2$ & $101,5 \pm 35,3$ & $76,2 \pm 28,9$ & $77,3 \pm 31,0$ & $\begin{array}{l}\mathrm{KW}=14,7 \\
\mathrm{P}=0,002 *\end{array}$ \\
\hline $\begin{array}{l}\text { HDL cholesterol } \\
(\mathrm{mg} / \mathrm{dl})\end{array}$ & $36,9 \pm 11,9$ & $29,4 \pm 9$ & $24,6 \pm 8,3$ & $28,7 \pm 12,5$ & $\begin{array}{l}\mathrm{KW}=13,0 \\
\mathrm{P}=0,005^{*}\end{array}$ \\
\hline $\begin{array}{l}\text { Total } \\
\text { cholesterol } \\
(\mathrm{mg} / \mathrm{dl})\end{array}$ & $189,0 \pm 61,7$ & $157,9 \pm 57,0$ & $141,7 \pm 55,9$ & $140,0 \pm 45,2$ & $\begin{array}{l}\mathrm{KW}=10,3 \\
\mathrm{P}=0,016^{*}\end{array}$ \\
\hline $\begin{array}{l}\text { C reactive } \\
\text { protein }(\mathrm{mg} / \mathrm{L})\end{array}$ & $8,7 \pm 9,2$ & $16,8 \pm 10,8$ & $21,4 \pm 12,2$ & $22,1 \pm 23,2$ & $\begin{array}{l}\mathrm{KW}=12,4 \\
\mathrm{P}=0,006^{*}\end{array}$ \\
\hline Albumin (g/dl) & $3,4 \pm 0,9$ & $3,1 \pm 0,71$ & $2,3 \pm 0,7$ & $2,8 \pm 0,6$ & $\begin{array}{l}\mathrm{KW}=22,4 \\
\mathrm{P}=0,001 *\end{array}$ \\
\hline $\begin{array}{l}\text { Parathormon } \\
(\mathrm{pg} / \mathrm{ml})\end{array}$ & $39,2 \pm 18,3$ & $59,0 \pm 37,0$ & $277,3 \pm 124,7$ & $288,8 \pm 194,4$ & $\begin{array}{l}4 \\
\mathrm{KW}=45,7 \\
\mathrm{P}=0,001^{*}\end{array}$ \\
\hline $\begin{array}{l}\text { Creatinine } \\
(\mathrm{mg} / \mathrm{dl})\end{array}$ & $0,8 \pm 0,1$ & $0,8 \pm 0,1$ & $6,9 \pm 2,3$ & $7,0 \pm 3,0$ & $\begin{array}{l}\mathrm{KW}=65,8 \\
\mathrm{P}=0,001^{*}\end{array}$ \\
\hline $\begin{array}{l}\text { Creatinine } \\
\text { Clearance } \\
(\mathrm{ml} / \mathrm{min})\end{array}$ & $110,8 \pm 23,0$ & $98,4 \pm 21,7$ & $12,5 \pm 6,1$ & $10,8 \pm 2,9$ & $\begin{array}{l}\mathrm{KW}=66,2 \\
\mathrm{P}=0,001^{*}\end{array}$ \\
\hline
\end{tabular}

$* \mathrm{P}<0.05$ statistically significant.

Table 2: Angiopoietin-related growth factor levels of the groups

\begin{tabular}{|l|l|}
\hline Group & AGF level $($ Mean \pm SD $)(\mu \mathrm{g} / \mathrm{L})$ \\
\hline Control $(\mathrm{n}=22)$ & $104,3 \pm 31,8$ \\
\hline Diabetic and normal GFR $(\mathrm{n}=22)$ & $249,0 \pm 84,4$ \\
\hline Diabetic and chronic hemodialysis $(\mathrm{n}=22)$ & $196,0 \pm 90,6$ \\
\hline Non-diabetic and chronic hemodialysis $(\mathrm{n}=22)$ & $175,9 \pm 72,3$ \\
\hline & $\mathrm{KW}=30,8 \mathrm{P}=0,001^{*}$ \\
\hline
\end{tabular}

$* \mathrm{P}<0.05$ statistically significant 
Table 3: Hemodialysis and angiopoietin-related growth factor levels

\begin{tabular}{|l|l|}
\hline & AGF Level $($ Mean \pm SD $)(\mu \mathrm{g} / \mathrm{L})$ \\
\hline Chronic hemodialysis patients $(\mathrm{n}=44)$ & $176,6 \pm 96,6$ \\
\hline Patients with normal GFR $(\mathrm{n}=44)$ & $186,0 \pm 81,7$ \\
\hline & $\mathrm{KW}=0,2 \mathrm{p}=0,626$ \\
\hline
\end{tabular}

$* \mathrm{P}<0.05$ statistically significant

Table 4: Type 2 Diabetes mellitus and angiopoietin-related growth factor levels

\begin{tabular}{|l|l|}
\hline AGF $(\mu \mathrm{g} / \mathrm{L})$ & Mean \pm SD \\
\hline Diabetic patients $(\mathrm{n}=44)$ & $222,56 \pm 90,61$ \\
\hline Non-diabetic patients $(\mathrm{n}=44)$ & $140,12 \pm 66,06$ \\
\hline Result & $\mathrm{KW}=23,78 \mathrm{p}=0,001^{*}$ \\
\hline
\end{tabular}

$* \mathrm{P}<0.05$ statistically significant

Table 5: Angiopoietin-related growth factor and various parameters correlation

\begin{tabular}{|l|l|l|}
\hline Parameters & Pearson correlation coefficient & $\mathrm{P}$ value \\
\hline Age & $\mathrm{r}=-0,356^{* *}$ & $\mathrm{P}=0,001^{* *}$ \\
\hline Gender & $\mathrm{r}=-0,639^{* *}$ & $\mathrm{P}=0,001^{* *}$ \\
\hline Body mass index & $\mathrm{r}=0,773^{* *}$ & $\mathrm{P}=0,001^{* *}$ \\
\hline HOMA-IR & $\mathrm{r}=0,, 814^{* *}$ & $\mathrm{P}=0,001^{* *}$ \\
\hline WHR & $\mathrm{r}=0,776^{* *}$ & $\mathrm{P}=0,001^{* *}$ \\
\hline Fasting blood sugar & $\mathrm{r}=0,557^{* *}$ & $\mathrm{P}=0,001^{* *}$ \\
\hline Fasting Insulin & $\mathrm{r}=0,760^{* *}$ & $\mathrm{P}=0,001^{* *}$ \\
\hline C reactive protein & $\mathrm{r}=0,737^{* *}$ & $\mathrm{P}=0,001^{* *}$ \\
\hline HDL & $\mathrm{r}=-0,770^{* *}$ & $\mathrm{P}=0,001^{* *}$ \\
\hline LDL & $\mathrm{r}=-0,090$ & $\mathrm{P}=0,407$ \\
\hline Total cholesterol & $\mathrm{r}=-0,123$ & $\mathrm{P}=0,252$ \\
\hline Trigylceride & $\mathrm{r}=-0,069$ & $\mathrm{P}=0,522$ \\
\hline Albumin & $\mathrm{r}=-0,099$ & $\mathrm{P}=0,357$ \\
\hline Creatinine & $\mathrm{r}=-0,058$ & $\mathrm{P}=0,593$ \\
\hline Creatinine clearance & $\mathrm{r}=-0,077$ & $\mathrm{P}=0,476$ \\
\hline Parathormon & $\mathrm{r}=-0,050$ & $\mathrm{P}=0,640$ \\
\hline
\end{tabular}

$* * \mathrm{P}<0.05$ statistically significant

\section{DISCUSSION}

Low level of persistence of proinflammatory pathways in adipose tissue activation improves systemic insulin resistance in obese individuals. It has been recently suggested that developing insulin resistance chronically activates proinflammatory pathways directly in adipose tissue. Various proinflammatory cytokines that affect adipose tissue and activate adipose tissue cells in an autocrine/paracrine fashion can be found on the surface of adipocytes and macrophages. Chronic kidney failure, decreased insulin sensitivity, insufficient insulin secretion, and increased hepatic gluconeogenesis contribute to insulin resistance. Insulin resistance in uremia is greatly reduced by dialysis. Clearing toxins in hemodialysis increases beta cell response to hyperglycemia and tissue sensitivity to insulin. There is no significant change in insulin level with hemodialysis.

This study aimed to evaluate the relationship of AGF with type $2 \mathrm{DM}$ and renal functions. In our study, no statistically significant decrease was found in AGF levels in hemodialysis patients. No significant correlation was found between AGF and creatine and creatinine clearance. This may be 
caused by the inclusion of patients with a GFR below $15 \mathrm{ml} / \mathrm{min}$ in our study. Since only patients with end-stage renal disease were included in this study, it does not provide information about AGF levels in patients with chronic kidney disease. Ebert at al. study suggest that renal dysfunction is negatively and T2DM is positively associated with AGF serum levels. It is thought that this negative correlation may be caused by decreased renal functions, decreasing serum AGF level or an inflammatory condition that contributes to AGF regulation in chronic dialysis patients. Further studies are needed to explain the relationship between AGF and renal functions.

A report revealed that human ANGPTL6 concentration in the circulation is increased in obesity or diabetes and ANGPTL6 concentration has a positive correlation with the fasting serum glucose levels ${ }^{8}$. Kadomatsu et al. suggested that ANGPTL6 resistance is likely to occur in obesity or diabetes ${ }^{9}$. ANGPTL6 levels were high in individuals who diagnosed with preeclampsia ${ }^{10}$, polycystic ovary syndrome ${ }^{11}$, and diabetes mellitus $6,8,13$.

In our study Serum AGF level showed significant correlation with diabetic patients.

In this study, the relationship between lipid panel and AGF was also investigated. A significant negative correlation was found between AGF and HDL. The relationship of AGF with fasting blood sugar and HDL can be explained by their being a component of metabolic syndrome. ANGPTL6 has a positive correlation to HOMA-IR and leptin ${ }^{5,13,15}$. A recent study showed elevated ANGPTL6 expression in the pharmacologic or genetic models of impaired mitochondrial oxidative phosphorylation ${ }^{14}$. ANGPTL6 expression is related with regulate adipose FGF2 $1{ }^{15}$. In recent prospective cohort study ANGPTL6 is a compensatory mechanism against metabolic stress and is a candidate biomarker of metabolic syndrome ${ }^{17}$. The function and receptors of AGF in the human body are still not fully understood. Further studies are needed to explain this.

A significant negative correlation was found between AGF and age. When the relationship between gender and AGF was evaluated, the level of AGF in men was found to be significantly higher than in women.

The relationship of C-reactive protein, which is an indicator of inflammation and is known to be correlated with endothelial dysfunction and insulin resistance, with AGF is also included in the studies. Ebert et al. showed a positive correlation between CRP and AGF in chronic hemodialysis patients ${ }^{5}$.
In our study, we showed that there is a significant positive correlation between AGF and CRP.

In our study, a significant positive correlation was found between AGF and body mass index, HOMAIR, WHR, and fasting blood sugar level. High levels of AGF in metabolic syndrome patients showed that AGF may be a predictor of metabolic syndrome.

As a result, although the relationship of AGF with diabetes mellitus and insulin resistance has been partially clarified, further studies are needed to elucidate its relationship with kidney functions.

\section{REFERENCES}

1.Reaven GM. The insulin resistance syndrome: definition and dietary approaches to treatment. Annu Rev Nutr . 2005; 25, 391- 406.

2.Kitazawa M, Ohizumi Y, Oike Y, Hishinuma T, Hashimoto S. Angiopoietin-related growth factor suppresses gluconeogenesis through the Akt/forkhead box class O1-dependent pathway in hepatocytes. J Pharmacol Exp Ther. 2007; Dec ;323(3):787-93.

3.Saini V. Molecular mechanisms of insulin resistance in type 2 diabetes mellitus. World $\mathbf{J}$ Diabetes. 2010; July 15; 1(3): 68-75.

4.Lu B, Yang Y. Insulin resistance in Chinese patients with type 2 diabetes is associated with Creactive protein independent of abdominal obesity. Cardiovascular Diabetology. 2010; 9:92.

5.Ebert T, Bachmann A, Lössner U, et al. Serum levels of angiopoietin-related growth factor in diabetes mellitus and chronic hemodialysis. Metabolism. 2009;58:547-51.

6.Abdullah B, Deveci K, Atilgan R, Kiliçli F, Söylemez MS. Serum angiopoietin-related growth factor (AGF) levels are elevated in gestational diabetes mellitus and associated with insulin resistance. Ginekol Pol. 2012 Oct;83(10):749-53.

7.Oike, Y. et al. Angiopoietin-related growth factor (AGF) promotes angiogenesis. Blood.2004; 103(10), 3760-3765.

8.Oike, Y. et al. Angiopoietin-related growth factor antagonizes obesity and insulin resistance. Nat Med. 2005; 11(4), 400-408.

9.Kadomatsu T, Tabata M, Oike Y. Angiopoietinlike proteins: emerging targets for treatment of obesity and related metabolic diseases. FEBS J. 2011;278:559-64.

10.Stepan H, Ebert T, Schrey S, Reisenbuchler C, Stein S, Lossner U, Bluher M, Stumvoll M, Kratzsch J, Faber R, Fasshauer M. Serum levels of 
angiopoietin-related growth factor are increased in preeclampsia. Am J Hypertens 2009;22:314-8.

11.Boztosun A, Deveci K, Klcl F, Soylemez MS, Muhtaroglu S. Serum levels of angiopoietin-related growth factor (AGF) are increased in polycystic ovary syndrome. J Investig Med 2012;60:813-7.

12.Ebert T, Kralisch S, Loessner U, Jessnitzer B, Stumvoll M, Fasshauer M, Tonjes A. Relationship between serum levels of angiopoietin-related growth factor and metabolic risk factors. Horm Metab Res 2014;46:685-90.

13.Namkung J, Koh SB, Kong ID, Choi JW, Yeh BI. Serum levels of angiopoietin-related growth factor are increased in metabolic syndrome. Metabolism 2011;60:564-8.

14.Kim KH, Jeong YT, Oh H, Kim SH, Cho JM, Kim YN, Kim SS, Kim DH, Hur KY, Kim HK, Ko T, Han J, Kim HL, Kim J, Back SH, Komatsu M, Chen H, Chan DC, Konishi M, Itoh N, Choi CS,
Lee MS. Autophagy deficiency leads to protection from obesity and insulin resistance by inducing Fgf21 as a mitokine. Nat Med 2013;19:83-92.

15.Kim MJ, Namkung J, Chang JS, Kim SJ, Park KS, Kong ID. Leptin regulates the expression of angiopoietin-like 6. Biochem Biophys Res Commun 2018;502:397-402.

16.Kang SG, Yi HS, Choi MJ, Ryu MJ, Jung S, Chung HK, Chang JY, Kim YK, Lee SE, Kim HW, Choi H, Kim DS, Lee JH, Kim KS, Kim HJ, Lee $\mathrm{CH}$, Oike Y, Shong M. ANGPTL6 expression is coupled with mitochondrial OXPHOS function to regulate adipose FGF21. J Endocrinol 2017;233:105-18.

17.Jun Namkung, Joon HS , Jae SC, Sang- WP, Jang Y, Sang-BK, In Deok K, Kyu-Sang P. Increased Serum Angiopoietin-Like 6 Ahead of Metabolic Syndrome in a Prospective Cohort Study. Diabetes Metab J 2019;43:521-529 